\title{
Economic Shocks and Civil Conflict:
}

\section{A Comment}

by

Antonio Ciccone*

February 2011

\begin{abstract}
Miguel, Satyanath, and Sergenti (2004) argue that lower rainfall levels and negative rainfall shocks increase conflict risk in Sub-Saharan Africa. This conclusion rests on their finding of a negative correlation between conflict in $t$ and rainfall growth between $t-1$ and $t-2$. I argue that this finding is driven by a positive correlation between conflict in $t$ and rainfall levels in $t$-2. If lower rainfall levels or negative rainfall shocks increased conflict, one might have expected MSS's finding to reflect a negative correlation between conflict in $t$ and rainfall levels in $t$-1. In the latest data, conflict is unrelated to rainfall.
\end{abstract}

Key words: Transitory shocks, mean reversion, civil conflict JEL codes: O0, P0, Q0

* ICREA-Universitat Pompeu Fabra and Barcelona GSE, antonio.ciccone@upf.edu. This paper was previously entitled “Transitory Economic Shocks and Civil Conflict.” I am grateful to Natalie Chen, Esther Duflo, Edward Miguel, Shanker Satyanath, Ernest Sergenti, Kurt Schmidheiny, two referees, and participants at the "Conflicts, Globalization, and Development" CEPR/PSE Workshop for comments. I also thank Halvard Buhaug for sharing his temperature data, Philipp Ager and Walter Garcia-Fontes for help with the rainfall data, and Andrea Tesei for excellent research assistance. Research support from CREI, FEDEA-BBVA, and Spanish Ministry of Science grants SEJ2007-64340 and ECO2008-02779 is gratefully acknowledged. 
Does poor economic performance cause violent civil conflict? Collier and Hoeffler's (1998, 2004) and Fearon and Laitin's (2003) empirical work suggests this is the case. Their findings are not based on exogenous changes in the economic environment however, and could reflect feedback from conflict to economic performance or omitted social and political factors. To address these concerns, Miguel, Satyanath, and Sergenti (MSS, 2004) examine the link between (exogenous) rainfall and civil conflict in Sub-Saharan Africa 1979-1999. Their empirics lead them to the conclusion that higher levels of rainfall are associated with significantly less conflict (e.g. MSS, page 737). Or, equivalently, lower rainfall levels are associated with significantly more conflict. MSS explain this association by negative rainfall shocks reducing incomes and thereby increasing conflict risk. Their focus on exogenous rainfall shocks is an important step forward. MSS's study has advanced quickly to one of the most cited articles on civil conflict, and their conclusion has become a cornerstone of the literature on the economics of civil conflict (e.g. Collier and Hoeffler, 2005; Collier, Hoeffler, and Rohner, 2009; Hegre and Sambanis, 2006; Fisman and Miguel, 2009). ${ }^{1}$

MSS's (2004) interpretation of the Sub-Saharan African rainfall and civil conflict data rests on their finding of a negative correlation between civil conflict in year $t$ and the year-onyear rainfall growth rate between $t-1$ and $t-2$. I argue that this finding is driven by a positive correlation between conflict in year $t$ and rainfall levels in year $t-2$. If conflict was triggered by lower rainfall levels or negative rainfall shocks, one would have expected the negative correlation found by MSS to reflect a negative correlation between conflict in $t$ and rainfall

${ }^{1}$ MSS is the 7th most cited article on the topics civil conflict or civil war in history, economics, political sciences, and sociology according to the ISI Web of Knowledge http://isiwebofknowledge.com/. 
levels in $t-1$. As civil conflict risk in MSS's data is not higher following low rainfall levels or negative rainfall shocks, I argue that MSS's interpretation is an artifact of their empirical approach. The latest available datasets on rainfall and civil conflict in Sub-Saharan Africa have been extended to 2009. In these data, civil conflict risk is unrelated to year-on-year rainfall growth, rainfall levels, or rainfall shocks. This suggests that uncovering an effect of rainfall on civil conflict will require using more disaggregated data.

The main difference between my empirical approach and the empirical approach of MSS is that I focus on the correlation between civil conflict and current as well as lagged rainfall levels. To see why, it is useful to start with the question whether lower rainfall levels are associated with more or with less civil conflict. MSS answer this question by examining the correlation between civil conflict and current as well as past year-on-year rainfall growth, while I address this question by examining the correlation between civil conflict and current as well as past rainfall levels. ${ }^{2}$ These two empirical approaches (growth versus levels) need not yield the same answer as years with low year-on-year rainfall growth need not be years where rainfall levels are low. For example, low year-on-year rainfall growth may reflect that rainfall levels fell from a high level to the historical mean. To understand why MSS and I also reach different conclusions regarding the link between rainfall shocks and civil conflict, it is important to note that MSS's empirical approach uses year-on-year rainfall growth as a measure of rainfall shocks (MSS, page 733). As rainfall levels are strongly mean reverting, rainfall growth between two years $t$ and $t-1$ may be low because of a negative rainfall shock in $t$ or because of a positive rainfall shock in $t-1$. Put differently, because rainfall shocks are transitory, low rainfall growth may reflect negative shocks or mean reversion following

${ }^{2}$ Burke, Miguel, Satyanath, Dykema, and Lobell's (2009) and Buhaug's (2010) investigation of the effect of global warming on civil war risk in Africa also focuses on rainfall levels rather than rainfall growth rates. 
positive shocks. Inferring the effect of rainfall (transitory) shocks on civil conflict from the effect of year-on-year rainfall growth may therefore be misleading.

To see these points more precisely, it is useful to consider MSS's linear-probability model linking civil conflict to rainfall. Their model predicts the probability of civil conflict PPconflict $t_{t}$ in year $t$ based on current and lagged year-on-year rainfall growth,

$$
\text { PPconflict } t_{t}=a^{L S} R G r_{t}+b^{L S} R G r_{t-1} \text {, }
$$

where $R G r_{t}$ is rainfall growth between year $t$ and $t-1$, and $a^{L S}, b^{L S}$ are least-squares estimates. MSS find a statistically insignificant value for $a^{L S}$ and a statistically significant, negative value for $b^{L S}$. They then use this finding to make inferences about the effect of rainfall levels and rainfall shocks on conflict. To examine whether such inferences are feasible, suppose that rainfall levels are distributed identically and independently over time. This implies that rainfall levels are strongly mean reverting and that rainfall shocks are transitory. ${ }^{3}$ Suppose also that the true probability of conflict Pconflict depends on current and lagged log rainfall levels $(\log R)$,

$$
\text { Pconflict } t_{t}=\alpha_{0} \log R_{t}+\alpha_{1} \log R_{t-1}+\alpha_{2} \log R_{t-2} .
$$

If $\alpha_{i}>0$ for $i=0,1,2$, the probability of conflict is lower following low rainfall levels and negative rainfall shocks (lower than expected rainfall levels). ${ }^{4}$ Now imagine running a leastsquares regression to predict the probability of conflict based on current and lagged year-on-

\footnotetext{
${ }^{3}$ Empirically, rainfall levels are strongly mean reverting. For example, regressing log rainfall levels on lagged log rainfall levels using MSS's data and controlling for country fixed effects, yields a system-GMM coefficient on lagged log rain of 0.17 with a standard error of 0.04 . Accounting for the empirical persistence of rainfall does not affect the conclusion but complicates the coefficient formulas in (3).

${ }^{4}$ For an insightful theoretical analysis of the link between transitory economic shocks and civil conflict see Chassang and Padró i Miquel (2009).
} 
year rainfall growth as in (1). The coefficients of this regression would be determined by the usual least-squares orthogonality conditions: $\operatorname{cov}\left(\right.$ Pconflict $\left._{t}-a^{L S} R G r_{t}-b^{L S} R G r_{t-1}, R G r_{t}\right)=\operatorname{cov}\left(\right.$ Pconflict $\left._{t}-a^{L S} R G r_{t}-b^{L S} R G r_{t-1}, R G r_{t-1}\right)=0$. Making use of (2) and $R G r_{t}=\log R_{t}-\log R_{t-1}$ in these conditions yields

$$
a^{L S}=\frac{2 \alpha_{0}-\left(\alpha_{1}+\alpha_{2}\right)}{3} \text { and } b^{L S}=\frac{\left(\alpha_{0}+\alpha_{1}\right)-2 \alpha_{2}}{3} .
$$

Hence, the least-squares estimates for $a^{L S}$ and $b^{L S}$ in (1) are mixtures of the parameters $\alpha_{i}$ determining the effects of rainfall levels and rainfall shocks on the probability of civil conflict in (2). As a result, the coefficients of the rainfall-growth specification in (1) are uninformative about the effect of rainfall levels or shocks and using them to make inferences about the effect of rainfall levels or shocks may be misleading. For example, $b^{L S}$ in (3) will be negative as long as $2 \alpha_{2}>\alpha_{0}+\alpha_{1}$. Hence, $b^{L S}$ may be negative although lower rainfall levels and negative rainfall shocks reduce conflict at all lags, i.e. $\alpha_{i}>0$ for $i=0,1,2$ in (2). It is even possible that both $a^{L S}$ and $b^{L S}$ are negative although lower rainfall levels and negative rainfall shocks reduce the probability of conflict at all lags. To see this, note that both coefficients in (3) will be negative if and only if $\alpha_{0}-\theta<\alpha_{1}<\alpha_{0}+2 \theta$ where $\theta=\alpha_{2}-\alpha_{0} .{ }^{6}$ As a result, if $\alpha_{2}>\alpha_{0}>0$,

\footnotetext{
${ }^{5}$ The assumption that $\log$ rain is i.i.d. implies that $\operatorname{cov}\left(\right.$ Pconflict $\left._{t}-a^{L S} R G r_{t}-b^{L S} R G r_{t-1}, R G r_{t}\right)$ simplifies to $\left(\alpha_{0}-\alpha_{1}-2 a^{L S}+b^{L S}\right) V$ and that $\operatorname{cov}\left(\right.$ Pconflict $\left._{t}-a^{L S} R G r_{t}-b^{L S} R G r_{t-1}, R G r_{t-1}\right)$ simplifies to $\left(\alpha_{1}-\alpha_{2}+a^{L S}-2 b^{L S}\right) V$ where $V$ is the variance of log rain. Hence, (3) can be obtained by solving $\alpha_{0}-\alpha_{1}-2 a^{L S}+b^{L S}=\alpha_{1}-\alpha_{2}+a^{L S}-2 b^{L S}=0$ for $a^{L S}, b^{L S}$. In practice one does not observe the probability of conflict but only whether there has been a conflict or not. This does not affect (3) however, see Wooldridge (2002), page 454.

${ }^{6}$ Lagged rain growth will enter negatively if and only if $2 \alpha_{2}>\alpha_{0}+\alpha_{1}$, or equivalently $\alpha_{1}<2 \alpha_{2}-\alpha_{0}=2 \theta+\alpha_{0}$. Current rain growth will enter negatively if and only if $2 \alpha_{0}<\alpha_{1}+\alpha_{2}$, or equivalently $\alpha_{1}>2 \alpha_{0}-\alpha_{2}=\alpha_{0}-\theta$. Combining inequalities yields $\alpha_{0}-\theta<\alpha_{1}<\alpha_{0}+2 \theta$.
} 
both current and lagged rainfall growth can enter (1) negatively, even if lower rainfall levels and negative rainfall shocks decrease the conflict probability at all lags. ${ }^{7}$

The intuition for why one may find lower year-on-year rainfall growth to be associated with greater civil conflict risk even if negative rainfall shocks decrease conflict risk is the following. Imagine an economy experiencing a negative rainfall shock and that this shock makes it unlikely that there is a civil conflict in the following year. Now consider the situation in the following year. Because of last year's negative rainfall shock, civil conflict will be unlikely by assumption. Moreover, mean reversion implies that year-on-year rainfall growth will tend to be positive. Imposing the restriction that civil conflict can be related to rainfall growth only, as in (1), will therefore yield that civil conflict is less likely following positive rainfall growth. If one goes a step further and also assumes that rainfall growth is a measure of rainfall shocks, the conclusion becomes that civil conflict is less likely following positive rainfall shocks.

The bottom line is that rainfall-growth specifications as in (1) cannot be used to make inferences about the effect of rainfall levels or rainfall shocks on civil conflict, as a negative correlation between conflict and lagged year-on-year rainfall growth may not reflect higher civil conflict risk following lower rainfall levels or negative rainfall shocks. This concern turns out to be justified in MSS's data, as their finding of a negative correlation between civil conflict and year-on-year rainfall growth between $t-1$ and $t-2$ is driven by a (somewhat counter-intuitive) positive correlation between conflict and rainfall levels in year $t-2$.

Another advantage of rainfall-level specifications as in (2) is that they nest rainfall-growth specifications. This allows using rainfall-level specifications to test the restrictions implicit in

${ }^{7} \alpha_{2}>\alpha_{0}$ implies that $\theta>0$ and hence that there are values for $\alpha_{i} i=0,1,2$ that satisfy the inequality $\alpha_{0}-\theta<\alpha_{1}<\alpha_{0}+2 \theta . \alpha_{0}>0$ implies that these values can all be strictly positive. 
rainfall-growth specifications. For example, suppose the probability of civil conflict was in fact determined by lagged year-on-year rainfall growth,

$$
\text { Pconflict } t_{t}=\beta R G r_{t-1}=\beta\left(\log R_{t-1}-\log R_{t-2}\right) \quad \text { with } \quad \beta<0
$$

as suggested by MSS's (2004) findings. This rainfall-growth specification is equivalent to the rainfall-level specification

$$
\text { Pconflict }_{t}=\beta \log R_{t-1}-\beta \log R_{t-2} \quad \text { with } \quad \beta<0 .
$$

Hence, the rainfall-growth specification in (4) implies a negative coefficient on $t-1$ rainfall in a rainfall-level specification. This is quite intuitive: if high civil conflict risk was in fact caused by falling rainfall between $t-2$ and $t-1$, lower $t-1$ rainfall should be associated with greater civil conflict risk when $t-2$ rainfall is held constant. Rejection of the hypothesis that $t-1$ rainfall enters negatively in a rainfall-level specification implies rejection of the rainfall-growth specification in (4). I find that the data fail to support the hypothesis that $t-1$ rainfall enters negatively in a rainfall-level specification.

While the growth specification in (1) does not allow uncovering whether civil conflict is caused by transitory (rainfall) shocks, it can be used to examine whether conflict is caused by permanent shocks. To see this, suppose that the driving variable $\log x_{t}$ follows a random walk $\log x_{t}=\log x_{t-1}+\varepsilon_{t}$, where $\varepsilon_{t}$ is distributed identically and independently over time and has mean zero. In this case, year-on-year growth of the driving variable $\log x_{t}-\log x_{t-1}$ is equal to the (permanent) shock $\varepsilon_{t}$. Hence, the effect of shocks on civil conflict can be uncovered using a growth specification. This is why examining the link between conflict and commodity price shocks—which are typically very persistent, see Cashin, Liang, and McDermott (2000) and Brückner and Ciccone (2010)—requires a different approach than examining the link between conflict and rainfall shocks. 
The remainder of the paper examines the link between rainfall and civil conflict using the dataset employed by MSS as well as the latest available data. Additional empirical results can be found in a Web Appendix available at www.antoniociccone.eu.

\section{Does civil conflict follow lower rainfall levels or negative rainfall shocks?}

The conflict data come from the UCPD/PRIO Armed Conflict Database. ${ }^{8}$ The rainfall data come from the Combined Precipitation Dataset of NASA's Global Precipitation Climatology Project (GPCP; these data are only available since 1979). ${ }^{9}$

UCPD/PRIO defines conflict as "a contested incompatibility which concerns government and/or territory where the use of armed force between two parties, of which at least one is the government of a state, results in at least 25 battle-related deaths.” MSS's (2004) definition of civil conflict includes all internal armed conflicts without any intervention from other states and all internal armed conflicts with intervention from other states. ${ }^{10}$

I report results on the link between rainfall and either civil conflict onset or conflict incidence. Civil conflict onset is an indicator variable that captures conflict outbreak. The onset indicator in year $t$ is 1 if there is a civil conflict in $t$ but there was no conflict in $t-1 ; 0$ if there is no conflict in $t$ and there was no conflict in $t-1$; and not defined if there was a conflict

${ }^{8}$ See Gleditsch, Wallensteen, Sollenberg, and Strand (2002). For the conflict data see http://www.prio.no/CSCW/Datasets/ Armed-Conflict/UCDP-PRIO/.

${ }^{9}$ Which in contrast to the datasets covering the period before 1979 employs both gauge and satellite measurements. See Adler et al. (2003) and http://precip.gsfc.nasa.gov.

${ }^{10}$ As pointed out by Jensen and Gleditsch (2009), MSS's definition of civil conflict implies that some countries are classified as experiencing a civil conflict although there is no civil conflict on their territory. This is the case when these countries participate in civil conflicts in other states (participate in extraterritorial civil conflicts). Jensen and Gleditsch argue that participation in extraterritorial civil conflicts does not fit MSS's narrative and therefore focus on the determinants of civil conflicts fought on the country's territory (i.e. exclude participation in extraterritorial conflicts). For results excluding extraterritorial civil conflicts, see the Web Appendix. 
in $t-1$. Conflict incidence, on the other hand, is an indicator variable that is 1 if there is a conflict in $t$ and 0 if there is not. Hence, the conflict incidence indicator may be 1 because of the outbreak of a new conflict or the continuation of an existing conflict. Rainfall in year $t$ is calculated as average annual rainfall.

All tables report two standard errors for each least-squares estimate. The standard errors in parentheses are consistent for arbitrary heteroskedasticity and time-series correlation within each country cluster. The standard errors in square brackets also make a small-sample adjustment. The statistical theory behind hypothesis tests using the small-sample-adjusted standard errors assumes normally distributed and homoskedastic residuals (e.g. Greene, 1990, page 161). Both the normality assumption and the homoskedasticity assumption are violated in (my) linear probability models, where the left-hand-side variable is either 0 or 1 (e.g. Wooldridge, 2002, page 454). I report standard errors incorporating the small-sample adjustment to facilitate comparison with MSS (2004) and Miguel and Satyanath (2010).

The empirical results reported in the paper are based on least-squares regressions and, following MSS (2004), control for country-specific intercepts and country-specific linear time trends. $^{11}$

\section{II.A. Civil conflict onset (outbreak)}

I first examine the link between rainfall and civil conflict onset in MSS's (2004) data and then turn to the latest versions of the databases employed by MSS.

\footnotetext{
${ }^{11}$ For results controlling for common time-varying shocks to conflict risk, like the end of the Cold War for example (e.g. Fearon and Laitin, 2003), see the Web Appendix.
} 


\section{II.A.1. Conflict onset and rainfall in MSS's (2004) data}

Table 1, columns (1)-(2) contain results using MSS’s (2004) data for the 1979-1999 period, which come from UCPD/PRIO and the GPCP. (As MSS control for contemporaneous and lagged year-on-year rainfall growth and the GPCP rainfall data start in 1979, the earliest civil conflict onset observations employed correspond to 1981.) Column (1) shows that a leastsquares regression of conflict onset in year $t$ on current and lagged year-on-year rainfall growth yields a significantly negative coefficient on year $t-1$ rainfall growth (year-on-year rainfall growth between $t-1$ and $t-2$ ). The coefficient on $t-1$ rainfall growth is significant at the 90\% confidence level, no matter which standard error is used. Does this empirical result imply that conflict onset is more likely following lower rainfall levels or negative rainfall shocks? This question can be answered by regressing conflict onset on current and lagged log rainfall levels as in column (2). This yields that conflict onset is less likely following lower $t-2$ rainfall levels and negative $t-2$ rainfall shocks. The estimate indicating that conflict onset is less likely following lower rainfall levels and negative rainfall shocks is significant at the $95 \%$ confidence level, no matter which standard error is used.

\section{II.A.2. Conflict onset and rainfall in the latest data}

The latest UCDP/PRIO conflict dataset, the Armed Conflict Database Version 4-2010, ${ }^{12}$ contains conflict data until 2009. The latest version of the GPCP rainfall data set, the Combined Precipitation Dataset Version 2.1, ${ }^{13}$ contains rainfall data until September 2009. These datasets allow me to examine the link between rainfall and civil conflict onset for the 1979-2009 period. The lack of rainfall data for the last three months of 2009 is unlikely to

${ }^{12}$ See UCDP/PRIO Armed Conflict Dataset Version 4-2010, Version History and Known Errata (2010).

${ }^{13}$ See Huffman and Bolvin (2009). 
affect results. For this to be the case, civil conflicts starting at the end of 2009 would have to be caused by rainfall in the last three months of the year. This seems unlikely, especially as the empirical results in Table 1 indicate that contemporaneous, annual rainfall levels do not affect civil conflict risk. Still, I will also comment on the results for the 1979-2008 period (which are very similar to results for 1979-2009). ${ }^{14}$

Table 1, columns (3)-(4) show that according to the latest data there is no significant link between civil conflict onset and rainfall levels or rainfall growth. ${ }^{15}$ This continues to be the case when I control for shocks to the probability of civil conflict onset that are common to all Sub-Saharan African countries, ${ }^{16}$ and when I focus on the $1979-2008$ period. ${ }^{17}$ When I control for rainfall and temperature, there is some evidence that civil conflict onset over the 19792008 period is less likely following low rainfall levels and negative rainfall shocks. ${ }^{18}$

\section{II.B. Civil conflict incidence}

I now turn to the link between rainfall and civil conflict incidence. Civil conflict incidence subsumes conflict onset (outbreak) and conflict continuation. Hence, the implicit assumption when using conflict incidence instead of conflict onset as the dependent variable is that rainfall affects conflict onset and conflict continuation in the same way.

\section{II.B.1. Conflict incidence and rainfall in MSS's (2004) data}

Table 2, column (1) uses the UCPD/PRIO and GPCP datasets for 1979-1999 employed by MSS (2004) to reproduce their result that a least-squares regression of conflict incidence on

\footnotetext{
${ }^{14}$ The full set of 1979-2008 results are in Web Appendix II.

${ }^{15}$ Nor is there evidence of statistically significant effects of rainfall growth.

${ }^{16}$ See Web Appendix Tables I.B.1 and I.C.1, Panel B, columns (3)-(4) and (7)-(8).

${ }_{17}^{17}$ See Web Appendix Tables II.A.1, II.B.1, and II.C.1, columns (3)-(4) and columns (7)-(8).

${ }^{18}$ See Web Appendix Table III.A. The 1979-2008 temperature data come from Buhaug, Hegre, and Strand (2010). For results using the 1981-2002 temperature data of Burke, Miguel, Satyanath, Dykema, and Lobell (2009), see Web Appendix Table III.C.
} 
current and lagged rainfall growth yields a significantly negative coefficient on $t-1$ rainfall growth. Columns (2) and (3) add lagged incidence to MSS's specification as the probability of civil conflict may depend on whether there already was a conflict in the previous year. Column (2) reports least-squares results while column (3) reports system-GMM results. ${ }^{19}$ Not surprisingly, there is significant persistence in conflict incidence: civil conflict is 28 percentage points more likely when there was a conflict in the previous year. The coefficients on current and lagged rainfall growth are similar to column (1).

Does the negative coefficient on lagged rainfall growth in the civil conflict incidence regressions in columns (2) and (3) imply that conflict incidence is associated with lower rainfall levels or that conflict follows negative rainfall shocks? The statistically significant estimates in columns (4) and (5) shed doubt on such a conclusion. Relating civil conflict incidence to current and lagged log rainfall levels yields that conflict is less likely following lower $t-2$ rainfall and that the coefficient on $t-2$ rainfall is statistically significant at the $90 \%$ confidence level according to the system-GMM result and the least-squares result with and without the small-sample adjustment. The results in columns (4) and (5) also imply that civil conflict incidence is less likely following negative rainfall shocks. ${ }^{20}$

${ }^{19}$ Least squares is inconsistent for a fixed time-series dimension (number of years), while system-GMM is consistent as the cross-sectional dimension goes to infinity even when the number of years is fixed, see Wooldridge (2002), page 304. There is no small-sample adjustment for system-GMM, which is why only one standard error is reported for these results.

${ }^{20}$ Miguel and Satyanath (2010) find a statistically insignificant effect of rainfall levels on conflict incidence using MSS's datasets. The explanation for the discrepancy with the results in Table 2 is that my sample has 743 observations just like MSS's sample, while Miguel and Satyanath lose 41 observations. The reason why Miguel and Satyanath lose 41 observations is best illustrated with an example. The first observation in MSS for Nigeria relates civil conflict incidence in 1981 to rainfall between 1981 and 1979 (their rainfall data only starts in 1979). To keep this observation when controlling for lagged civil conflict incidence, one has to use data on civil conflict incidence in Nigeria in 1980 from the UCDP/PRIO Armed Conflict Database Version 1.2a employed by MSS. I use these data and keep the observation, while 


\section{II.B.2. Conflict incidence and rainfall in the latest data}

Table 2, columns (6)-(9) examine the link between civil conflict incidence and rainfall over the 1979-2009 period using the UCDP/PRIO Armed Conflict Database Version 4-2010 and the GPCP Combined Precipitation Dataset Version 2.1. It can be seen that the data do not support the hypothesis that conflict incidence follows lower rainfall levels or negative rainfall shocks. If anything, the results point in the opposite direction. The data continue to reject the hypothesis that conflict incidence follows lower rainfall levels or negative rainfall shocks when I control for shocks to the probability of civil conflict that are common to all SubSaharan African countries, ${ }^{21}$ and when I focus on the 1979-2008 period (to avoid employing the rainfall data for 2009, which is based on January to September rainfall only). ${ }^{22}$ This continues to be the case when I also account for temperature. ${ }^{23}$

\section{Civil war and rainfall in the latest data}

UCPD/PRIO defines civil war as a civil conflict with more than 1000 annual battle-related casualties (UCDP/PRIO Armed Conflict Dataset Codebook, 2010). ${ }^{24}$ Table 3 examines the link between rainfall and civil war onset and incidence using the 1979-2009 data from the UCDP/PRIO Armed Conflict Database Version 4-2010 and the GPCP Combined Precipitation Dataset Version 2.1. Column (1) shows that a least-squares regression of war onset in year $t$ on current and lagged rainfall growth yields a significantly negative coefficient on rainfall growth

Miguel and Satyanath do not use these data and lose this observation. The result is that Miguel and Satyanath lose one observation for each of the 41 countries in MSS's sample.

${ }^{21}$ See Web Appendix Tables I.B.3 and I.C.3, Panel A, columns (8)-(10).

${ }^{22}$ See Web Appendix Table II.A.2, II.B.2, and II.C.2, Panel A, columns (8)-(10).

${ }^{23}$ See Web Appendix Table III.B for 1979-2008 and Web Appendix Table III.D for 19812002.

${ }^{24}$ MSS (2004) point out that the particular threshold chosen is arbitrary and Buhaug (2010) that the threshold may affect empirical results. Civil war results should therefore be interpreted with caution. 
in $t$. The coefficient is significant at the $90 \%$ confidence level, no matter which standard error is used. The corresponding rainfall level specification in column (4) shows that this result cannot be interpreted as civil war onset being more likely following low rainfall levels or negative rainfall shocks. According to the results in column (4), civil war onset is either significantly less likely following low rainfall levels and negative rainfall shocks in $t-1$ or unrelated to rainfall levels and shocks, depending on the standard error used. The table also shows that there is no statistically significant link between rainfall levels or rainfall shocks and civil war incidence. These results continue to hold when I control for shocks to the probability of civil war that are common to all Sub-Saharan African countries, ${ }^{25}$ and when I focus on the 1979-2008 period and control for temperature. ${ }^{26}$

\section{Conclusion}

Two of the conclusions of Miguel, Satyanath, and Sergenti's (2004) study of civil conflict and rainfall in Sub-Saharan Africa are that lower rainfall levels and adverse rainfall shocks increase conflict risk. These conclusions rest on their finding of a negative correlation between conflict in year $t$ and year-on-year rainfall growth between $t-1$ and $t-2$. I argue that such a negative correlation between conflict and lagged year-on-year rainfall growth may not reflect that civil conflict risk is higher following lower rainfall levels or adverse rainfall shocks. This concern turns out to be justified in MSS's data, as the negative correlation between civil

\footnotetext{
${ }^{25}$ See Web Appendix Tables I.B.4 and I.C.4, Panel B, columns (3)-(4) and Tables I.B.6 and I.C.6, Panel A, columns (8)-(10).

${ }^{26}$ See Web Appendix Tables II.A.3, II.B.3, and II.C.3, columns (3)-(4) and Web Appendix Tables II.A.4, Table II.B.4, Table II.C.4, Panel A, columns (8)-(10). The 1979-2008 results controlling for temperature are in Web Appendix Tables III.A and III.B. When I use the 19812002 temperature data of Burke, Miguel, Satyanath, Dykema, and Lobell (2009) there is some evidence that civil war is less likely following low rainfall levels and negative rainfall shocks, see Web Appendix Tables III.C and III.D.
} 
conflict and year-on-year rainfall growth between $t-1$ and $t-2$ found by MSS is driven by a (somewhat counter-intuitive) positive correlation between civil conflict and rainfall levels in year $t$-2. If civil conflict was triggered by lower rainfall levels or negative rainfall shocks, one would have expected the negative correlation found by MSS to reflect a negative correlation between civil conflict in $t$ and rainfall levels in $t-1$.

The latest available datasets on rainfall and civil conflict in Sub-Saharan Africa have been extended to 2009. In these data, civil conflict risk is unrelated to rainfall. This suggests that uncovering an effect of rainfall on civil conflict will require using more disaggregated data. 


\section{References}

Adler, R.F., G.J. Huffman, A. Chang, R. Ferraro, P. Xie, J. Janowiak, B. Rudolf, U. Schneider, S. Curtis, D. Bolvin, A. Gruber, J. Susskind, P. Arkin, and E. Nelkin (2003). "The Version 2 Global Precipitation Climatology Project (GPCP) Monthly Precipitation Analysis (1979Present).” Journal of Hydrometeorology 4: 1147-1167.

Buhaug, H. (2010). “Climate Not to Blame for African Civil Wars.” Proceedings of the National Academy of Sciences of the USA 107 (38): 16477-16482.

Buhaug, H., H. Hegre, and H Strand (2010). "Sensitivity Analysis of Climate Variability and Civil War.” PRIO Paper.

Burke M.B., E. Miguel, S. Satyanath, J.A. Dykema JA, and D.B. Lobell (2009). "Warming Increases the Risk of Civil War in Africa.” Proceedings of the National Academy of Sciences of the USA 106(37): 20670-20674.

Brückner, M. and A. Ciccone (2010). “International Commodity Prices, Growth, and Civil War in Sub-Saharan Africa.” The Economic Journal 544 (05): 519-534.

Cashin, P., H. Liang, and J. McDermott (2000). "How Persistent Are Shocks to World Commodity Prices?” IMF Staff Paper 47 (3): 177-217.

Chassang, S. and G. Padró i Miquel (2009). "Economic Shocks and Civil War." Quarterly Journal of Political Science 4 (3): 211-228.

Collier, P. and A. Hoeffler (1998). “On Economic Causes of Civil War.” Oxford Economic Papers 50 (3): 563-573.

Collier, P. and A. Hoeffler (2004). “Greed and Grievance in Civil War.” Oxford Economic Papers 56 (4): 563-596.

Collier, P. and A. Hoeffler (2005). “Resource Rents, Governance, and Conflict.” Journal of Conflict Resolution 49 (4): 625-633.

Collier, P., A. Hoeffler, and D. Rohner (2009). “Beyond Greed and Grievance: Feasibility and Civil War.” Oxford Economic Papers 61 (2): 1-27.

Fearon, J. and D. Laitin (2003). “Ethnicity, Insurgency and Civil War.” American Political Science Review 97 (2): 75-90. 
Fisman, R. and E. Miguel (2009). Economic Gangsters. Princeton University Press, Princeton, NJ.

Gleditsch, N.P., P. Wallensteen, M. Eriksson, M. Sollenberg and H. Strand (2002). “Armed Conflict 1946-2001: A New Dataset.” Journal of Peace Research 39(5): 615-637.

Greene, W.H. (1990). Econometric Analysis. Macmillan. New York, NY.

Hegre, H. and N. Sambanis (2006). "Sensitivity Analysis of Empirical Results on Civil War Onset.” Journal of Conflict Resolution 50 (4): 508-535.

Huffman, G. and D. Bolvin (2009). “GPCP Version 2.1, Combined Precipitation Data Set Documentation” Laboratory for Atmospheres, NASA Goddard Space Flight Center and Science Systems and Applications. ftp://precip.gsfc.nasa.gov/pub/gpcpv2.1/doc/V2.1_doc.pdf

Jensen, P.S. and K.S. Gleditsch (2009). "Rain, Growth and Civil War: the Importance of Location”. Defence and Peace Economics 20 (5): 359-372.

Miguel, E., S. Satyanath, and E. Sergenti (2004). "Economic Shocks and Civil Conflict: An Instrumental Variables Approach.” Journal of Political Economy 112 (41): 725-753.

Miguel, E. and S. Satyanath (2010) "Understanding Transitory Rainfall Shocks, Economic Growth and Civil Conflict.” NBER WP 16461, October.

UCDP/PRIO Armed Conflict Dataset Codebook (2010). Version 4-2010. http://www.pcr.uu.se/digitalAssets/19/19230_Codebook_UCDP_PRIO_Armed_Conflict_D ataset_v4_2010.pdf

UCDP/PRIO Armed Conflict Dataset Version 4-2010, Version History and Know Errata (2010). http://www.pcr.uu.se/digitalAssets/19/19232_Version_history_v4-2010.pdf

Wooldridge, J.M. (2002). Econometric Analysis of Cross Section and Panel Data. MIT Press, Cambridge, MA. 


\section{Tables}

Table 1. Rainfall and civil conflict onset

\begin{tabular}{|c|c|c|c|c|}
\hline & \multicolumn{2}{|c|}{$\begin{array}{c}\text { MSS (2004) data, } \\
\text { which are for 1979-1999 }\end{array}$} & \multicolumn{2}{|c|}{$\begin{array}{c}\text { latest data, } \\
\text { which are for 1979-2009 }\end{array}$} \\
\hline & (1) & (2) & (3) & (4) \\
\hline Rainfall Growth, t & $\begin{array}{l}-0.063 \\
(0.044) \\
{[0.048]}\end{array}$ & & $\begin{array}{c}-0.037 \\
(0.029) \\
{[0.031]}\end{array}$ & \\
\hline Rainfall Growth, t-1 & $\begin{array}{c}-0.120^{*} \\
(0.062) \\
{[0.068]}\end{array}$ & & $\begin{array}{l}-0.052 \\
(0.033) \\
{[0.036]}\end{array}$ & \\
\hline Log Rainfall, t & & $\begin{array}{c}-0.073 \\
(0.078) \\
{[0.086]}\end{array}$ & & $\begin{array}{c}0.005 \\
(0.041) \\
{[0.044]}\end{array}$ \\
\hline Log Rainfall, t-1 & & $\begin{array}{l}-0.026 \\
(0.069) \\
{[0.075]}\end{array}$ & & $\begin{array}{c}0.023 \\
(0.042) \\
{[0.044]}\end{array}$ \\
\hline Log Rainfall, t-2 & & $\begin{array}{c}0.156 * * \\
(0.068) \\
{[0.074]}\end{array}$ & & $\begin{array}{c}0.074 \\
(0.052) \\
{[0.056]}\end{array}$ \\
\hline $\begin{array}{l}\text { Country FE and } \\
\text { Trend }\end{array}$ & Yes & Yes & Yes & Yes \\
\hline Observations & 555 & 555 & 873 & 873 \\
\hline \multicolumn{5}{|c|}{$\begin{array}{l}\text { Note: The left-hand-side variable is an indicator variable capturing civil conflict onset (see p. } 7 \text { in } \\
\text { the main text). The method of estimation is least squares. Standard errors in parentheses are robust } \\
\text { for arbitrary heteroskedasticity and clustered at the country level. Standard errors in square brackets } \\
\text { also apply the STATA small-sample adjustment (see p. } 8 \text { in the main text). *Significantly different } \\
\text { from zero at } 90 \text { percent confidence, } * * 95 \text { percent confidence, *** } 99 \text { percent confidence. When the } \\
\text { asterisks are next to the least-squares point estimate, the confidence level applies no matter which } \\
\text { of the two standard errors is employed. When the asterisks are next to the standard error, the } \\
\text { confidence level applies to that standard error only. }\end{array}$} \\
\hline
\end{tabular}


Table 2. Rainfall and civil conflict incidence

MSS (2004) data, which are for 1979-1999

\begin{tabular}{|c|c|c|c|c|c|c|c|c|c|}
\hline & & & & & & \\
\hline & (1) & (2) & (3) & (4) & (5) & (6) & (7) & (8) & (9) \\
\hline & LS & LS & GMM & LS & GMM & LS & GMM & LS & GMM \\
\hline Rainfall Growth, t & $\begin{array}{c}-0.024 \\
(0.040) \\
{[0.043]}\end{array}$ & $\begin{array}{c}-0.025 \\
(0.040) \\
{[0.043]}\end{array}$ & $\begin{array}{c}-0.017 \\
(0.043)\end{array}$ & & & $\begin{array}{c}-0.044 \\
(0.048) \\
{[0.050]}\end{array}$ & $\begin{array}{l}-0.047 \\
(0.05)\end{array}$ & & \\
\hline Rainfall Growth, t-1 & $\begin{array}{c}-0.122 * * \\
(0.048) \\
{[0.052]}\end{array}$ & $\begin{array}{c}-0.129 * * \\
(0.048) \\
{[0.051]}\end{array}$ & $\begin{array}{c}-0.123^{* *} \\
(0.049)\end{array}$ & & & $\begin{array}{c}-0.04 \\
(0.034) \\
{[0.036]}\end{array}$ & $\begin{array}{l}-0.045 \\
(0.038)\end{array}$ & & \\
\hline Log Rainfall, t & & & & $\begin{array}{c}-0.053 \\
(0.060) \\
{[0.065]}\end{array}$ & $\begin{array}{c}-0.033 \\
(0.063)\end{array}$ & & & $\begin{array}{c}0.04 \\
(0.067) \\
{[0.071]}\end{array}$ & $\begin{array}{l}0.039 \\
(0.07)\end{array}$ \\
\hline Log Rainfall, t-1 & & & & $\begin{array}{c}-0.102 \\
(0.069) \\
{[0.074]}\end{array}$ & $\begin{array}{c}-0.094 \\
(0.066)\end{array}$ & & & $\begin{array}{c}0.059 \\
(0.048) \\
{[0.051]}\end{array}$ & $\begin{array}{l}0.061 \\
(0.05)\end{array}$ \\
\hline Log Rainfall, t-2 & & & & $\begin{array}{c}0.128 * \\
(0.067) \\
{[0.072]}\end{array}$ & $\begin{array}{l}0.125 * \\
(0.064)\end{array}$ & & & $\begin{array}{c}0.076 \\
(0.044)^{*} \\
{[0.046]}\end{array}$ & $\begin{array}{c}0.084 * \\
(0.05)\end{array}$ \\
\hline Lagged Incidence & & $\begin{array}{c}0.277 * * * \\
(0.077) \\
{[0.083]}\end{array}$ & $\begin{array}{c}0.282 * * * \\
(0.077)\end{array}$ & $\begin{array}{c}0.274 * * * \\
(0.078) \\
{[0.084]}\end{array}$ & $\begin{array}{c}0.280 * * * \\
(0.078)\end{array}$ & $\begin{array}{c}0.369 * * * \\
(0.057) \\
{[0.06]}\end{array}$ & $\begin{array}{c}0.369 * * * \\
(0.057)\end{array}$ & $\begin{array}{c}0.367 * * * \\
(0.055) \\
{[0.058]}\end{array}$ & $\begin{array}{c}0.367 * * * \\
(0.055)\end{array}$ \\
\hline Country FE and Trend & Yes & Yes & Yes & Yes & Yes & Yes & Yes & Yes & Yes \\
\hline Observations & 743 & 743 & 743 & 743 & 743 & 1179 & 1179 & 1179 & 1179 \\
\hline
\end{tabular}


Table 3. Rainfall and civil war onset or incidence 1979-2009

\begin{tabular}{|c|c|c|c|c|c|c|}
\hline & (1) & (2) & (3) & (4) & (5) & (6) \\
\hline & $\begin{array}{c}\text { Onset } \\
\text { LS }\end{array}$ & $\begin{array}{c}\text { Incidence } \\
\text { LS }\end{array}$ & $\begin{array}{l}\text { Incidence } \\
\text { GMM }\end{array}$ & $\begin{array}{c}\text { Onset } \\
\text { LS }\end{array}$ & $\begin{array}{c}\text { Incidence } \\
\text { LS }\end{array}$ & $\begin{array}{c}\text { Incidence } \\
\text { GMM }\end{array}$ \\
\hline Rainfall Growth, t & $\begin{array}{l}-0.036^{*} \\
(0.019) \\
{[0.020]}\end{array}$ & $\begin{array}{l}-0.047 \\
(0.030) \\
{[0.031]}\end{array}$ & $\begin{array}{l}-0.055 \\
(0.034)\end{array}$ & & & \\
\hline Rainfall Growth, t-1 & $\begin{array}{c}0.004 \\
(0.018) \\
{[0.019]}\end{array}$ & $\begin{array}{l}-0.017 \\
(0.022) \\
{[0.023]}\end{array}$ & $\begin{array}{l}-0.024 \\
(0.024)\end{array}$ & & & \\
\hline Log Rainfall, t & & & & $\begin{array}{c}-0.029 \\
(0.03) \\
{[0.032]}\end{array}$ & $\begin{array}{l}-0.039 \\
(0.045) \\
{[0.047]}\end{array}$ & $\begin{array}{l}-0.048 \\
(0.053)\end{array}$ \\
\hline Log Rainfall, t-1 & & & & $\begin{array}{c}0.051 \\
(0.03)^{*} \\
{[0.032]}\end{array}$ & $\begin{array}{c}0.039 \\
(0.032) \\
{[0.034]}\end{array}$ & $\begin{array}{c}0.038 \\
(0.032)\end{array}$ \\
\hline Log Rainfall, t-2 & & & & $\begin{array}{l}-0.006 \\
(0.026) \\
{[0.026]}\end{array}$ & $\begin{array}{c}0.02 \\
(0.035) \\
{[0.036]}\end{array}$ & $\begin{array}{l}0.024 \\
(0.04)\end{array}$ \\
\hline Lagged Incidence & & $\begin{array}{c}0.277 * * * \\
(0.077) \\
{[0.083]}\end{array}$ & $\begin{array}{c}0.282^{* * *} \\
(0.077)\end{array}$ & & $\begin{array}{c}0.416^{* * *} \\
(0.051) \\
{[0.054]}\end{array}$ & $\begin{array}{c}0.416^{* * *} \\
(0.051)\end{array}$ \\
\hline Country FE and Trend & Yes & Yes & Yes & Yes & Yes & Yes \\
\hline Observations & 1036 & 1179 & 1179 & 1036 & 1179 & 1179 \\
\hline \multicolumn{7}{|c|}{$\begin{array}{l}\text { Note: The left-hand-side variable is an indicator variable capturing civil war onset or incidence (see } \\
\text { p.7 in the main text). The method of estimation is least squares or system-GMM. Standard errors in } \\
\text { parentheses are robust for arbitrary heteroskedasticity and clustered at the country level. Standard } \\
\text { errors in square brackets also apply the STATA small-sample adjustment (see p.8 in the main text). } \\
\text { *Significantly different from zero at } 90 \text { percent confidence, ** } 95 \text { percent confidence, *** } 99 \text { percent } \\
\text { confidence. When the asterisks are next to the least-squares point estimate, the confidence level } \\
\text { applies no matter which of the two standard errors is employed. When the asterisks are next to the } \\
\text { standard error, the confidence level applies to that standard error only. }\end{array}$} \\
\hline
\end{tabular}

